\title{
A sportolói kettős karrier fejlesztési lehetőségeinek vizsgálata Magyarországon
} \section{Chances of Dual Career Development in Sport in Hungary}

\author{
Farkas Judit', Jókai Mátyás ${ }^{1}$, Kozsla Tibor² \\ 1 Testnevelési Egyetem, Minőségbiztosítási és Akkreditációs Iroda, Budapest
}

2 European Athlete as Student Network, Budapest

\begin{abstract}
Absztrakt: Európaszerte ismert téma, de hazánkban kevés jó gyakorlattal rendelkezik a sportolók kettős karrierjének rendszerszintú, fenntartható támogatása. A Magyarországon múködô két támogatási program kezdeményezettjeinek köre szúk, hiszen csak azokat a felsóoktatásban tanuló sportolókat támogatja, akik tanulmányaik ideje alatt eséllyel rendelkeznek nemzetközi versenyen való éremszerzésre. A tanulmányban a fejlesztésekhez készült hazai és európai uniós szakpolitikai dokumentumok bemutatása mellett az egy központosított uniós projektben nyert kérdóíves kutatási adatok egy részét is feldolgoztuk, ismertetjük ( $n=320,38$ sportág). A válaszadó sportolók úgy értékelték, hogy az összes felsorolt (19 féle) támogatási eszközre szükségük van. Bár magyar sportolói hangok, felmutatott érdekek, igények eddig nem voltak tapasztalhatók, és az unió a sport területén nyert puha kompetenciája sem kötelezi a tagállami, így a magyar sport állami és nem állami vezetését, hogy hajtsa végre a több uniós szakpolitikai dokumentumban rögzített iránymutatásokat/ ajánlásokat; a kutatásunkban született eredmények várhatóan mégis közelebb viszik a magyar sport több szereplójét ahhoz, hogy megvalósítsa a sportolói kettős karrierprogramok fejlesztését.
\end{abstract}

Kulcsszavak: sportolói kettős karrier, magyar és Európai Uniós szakpolitika

\begin{abstract}
The dual career of athletes is a well-known topic all over Europe, but there are still only a few good practices in Hungary about this type of supporting system for athletes. Both Hungarian dual career programs support only a small number of college/university student athletes, who have the chance to win a medal in an international competition. We have analyzed the key EU policy documents on dual career of athletes, but most of all, the authors share a centralized EU project's survey result on the opinion and views of the Hungarian athletes regarding the dual career services ( $n=320,38$ sports). From the results of the research we highlight that athletes felt they need all 19 types of listed supporting tools, e.g. personality development courses, educational counselling; scholarships; career counselling and planning; acquiring skills change management; amended curriculum; flexible test system; tutoring; distance learning; online learning; volunteer / internship work at sports organizations, for possible career with them later on. Since Hungarian athletes have not manifested their interests and needs before regarding the dual career services, the results of the study will hopefully raise major sport stakeholders' interest in working towards the introduction of a more comprehensive dual career services of athletes in Hungary, partly by implementing EU policy documents, e.g. EU guidelines on dual careers of athletes; Study on the minimum quality requirements for dual career services.
\end{abstract}

Keywords: dual career of athletes, Hungarian and EU sports policy

\section{Bevezetés}

Napjainkban már fiatal korban komoly kérdést jelent a pályaválasztás, karrierépítés. A középiskolás tanulók között hatalmas a verseny az egyetemi férőhelyekért. Kevesen engedhetik meg maguknak az önköltséges felsőoktatást, és a 4 éve egyes képzési területeken folyamatosan csökkenő államilag finanszírozott, ösztöndíjas férőhelyek száma csak élesebbé tette a versenyt. 
A 12-18 éves versenysportoló napi több órát edz/versenyez/utazik/regenerálódik miközben kortársai ezt az időt a középiskolába és felsőoktatásba való bekerüléshez szükséges többlettanulással, többletpont szerzéssel (pl. több nyelvvizsga) töltik/ tölthetik. A versenysportoló lényegében többnyire hátrányt halmozhat fel, de ennek tudományos vizsgálata még nem történt meg. A korábban visszavonult elit sportolók között egzisztenciális gondokkal küzdőkről is gyakran hallunk a híradásokban. Számos példát ismerünk, amikor a (volt) élsportoló, karrierje végén/után egzisztenciális gondokkal küzdött, mert nem tudta fenntartani az általa megszokott életszínvonalat. Mivel az adott sportoló nem rendelkezett szakképzettséggel, így munkát sem tudott vállalni, ill. vállalkozása és/vagy befektetése sem volt.

$\mathrm{Az}$ élsportolói karrier magában rejti a sérülés lehetőségét, ami kritikus esetben a karrier hirtelen befejezését eredményezheti. Ebben az esetben is szüksége van a volt sportolónak vagy megkezdett tanulmányokra vagy képesítésre, amivel tovább építheti civil karrierjét.

A sportolói kettős karrier jelentése nem más, mint a versenysportban és az oktatásban való egyidejű részvétel annak érdekében, hogy a sportkarrier után a képzettségének megfelelő munkát találhasson a munkaeröpiacon a volt sportoló (Kozsla és mtsai, 2014).

\section{A kettős karrier szakpolitikai háttere}

A kettős karrier témában egyre több, ám leginkább helyi érdekű hazai tanulmány születik (városi, egyetemi szintű). Európai szinten a kutatáshoz öt irányadó Európai Uniós szakpolitikai dokumentumot és egy korábbi hazai kutatást mutatunk be röviden.

\section{EU Fehér könyv a sportról}

$\mathrm{Ez}$ a 2007-ben kiadott stratégiai dokumentum volt az első, amiben a sporttal kapcsolatos fóbb ismereteket, adatokat gyüjtötték össze az Európai Unióban. A sportolói kettős karriert támogató rendszerek kialakításához a nemzeti szintű sportszövetségek munkáját emeli ki, illetve az Európát átívelő kutatásokat és az azokra alapozott szakpolitika-alkotás, és programok (evidence-based policy) fontosságát fogalmazza meg (Európai Bizottság, 2007).

\section{Közlemény a sport európai dimenzióinak fej- lesztéséröl}

Ez a dokumentum a Fehér könyv a sportról alapozó munka eredményeire épít. A Bizottság a Fehér könyv végrehajtása révén hasznos tapasztalatokat gyüjtött olyan témákat illetően, amelyekkel a sport területén a jövőben foglalkozni kell (Farkas, 2012). A kettős karrier témája markánsan jelenik meg a fejlesztendő területek között (Európai Bizottság, 2011a).

\section{EU iránymutatások a sportolók kettös karri- erjéröl}

A következő, már célirányosan a sportolói kettős karriert érintő szakpolitikai dokumentum 2012ben született, „EU Guidelines on Dual Careers of Athletes" címen. A dokumentumot a tagállamokból delegált 27 fös szakértői csoport állotta össze, és 36 iránymutatást tartalmaz, amelyek követésével maradéktalanul ki lehet építeni a sportolói kettős karrier rendszerét (Európai Bizottság, 2012).

\section{Oktatás, képzés és kettös karrier a sportban}

A 2014-ben publikált hazai Támop 6.1.2-es projekt keretében készült tanulmány a fent leírt 36 uniós iránymutatást lefordította és mérte fel megvalósulásának mértékét. A hazai helyzetelemzést követően a hazai körülményeket figyelembe véve fogalmaz meg ajánlásokat (Kozsla és mtsai, 2014).

Tanulmány a kettös karrier szolgáltatások minimális minöségi követelményeiröl

A harmadik átfogó uniós szakpolitikai dokumentum a témában, a "Study on the Minimum Quality Requirements for Dual Career Services" címen jelent meg 2015 végén. Hetvenkét szempontot tartalmaz, melyek megléte szükséges a sportolók kettős karrierjét támogató rendszer kialakításához (Európai Bizottság, 2015).

\section{A sportra vonatkozó uniós munkatervek}

További forrást jelentenek a hazai és uniós szintü fejlesztésekhez a már 2 alkalommal kiadott EU sportra vonatkozó uniós munkatervek (2011-14 és 2014-17) (Európai Bizottság, 2011b, és EB, 2014). A kettős karrier téma mindkét esetben megjelenik.

Hazai programok a sportolók kettős karrierjének támogatására

Magyarországon jelenleg két országos program 
létezik a kettős karrierrel kapcsolatban.

\section{Magyar Sportcsillag Ösztöndij-program}

Az ösztöndíj programot a magyar kormány hozta létre a felsőoktatásban részt vevő olyan sportolók támogatására, akik a tanulmányaik ideje alatt, olimpiai vagy paralimpiai sportágban világbajnoki, Európa-bajnoki vagy olimpiai éremszerzésre esélyesek. ${ }^{1}$

\section{Olimpikon Életút Program}

„A Magyar Olimpiai Bizottság elnöksége 2002. július 12-i ülésén úgy határozott, hogy az olimpiai válogatott keretek tagjai és az „olimpiai reménységek" kategóriájába tartozó sportolók karrierjének és a civil életre való felkészülésének összehangolása érdekében létrehozza az Olimpikon Életút Program elnevezésű támogatási rendszert."” A programban, a felsőoktatásban hallgatói jogviszonnyal rendelkező, olimpiai kerettagok vehetnek részt. Az anyagi támogatáson kívül a pályázó más kedvezményekre is jogosulttá válhat: tandíjcsökkentés, átvétel ösztöndíjas keretbe, kollégiumi elhelyezés, korrepetitor és egyéni tanulmányi/vizsgarend biztosítása.

A kutatás fö célja, hogy megtudjuk, mit gondolnak a sportolók a tanulásban/munkában és a sportban való párhuzamos részvételről, valamint azt, hogy milyen támogató eszközökre van szükségük.

\section{Kutatási kérdések}

Kutatásunkban arra keresünk választ, hogy:

1. Előfordul-e, hogy a sportoló nem tudja összehangolni a tanulást és a sportolást.

2. Foglalkoztatja-e őket a sportolói karrier utáni élet?

3. A sportszervezetek mennyire veszi ki a részüket a sportolók sportkarrieren kívüli fejlesztéséből?

4. Mennyire érzik fontosnak a civil életre való átállás szempontjából, hogy ezzel kapcsolatos tanácsadáson, programokon vegyenek részt?

5. Mennyire éreznék segítségnek a tanulmányaik során, ha az oktatásban személyre szabott feltételekkel vehetnének részt?

${ }^{1}$ http://emmiugyfelszolgalat.gov.hu/felsooktatas/ magyar-sportcsillagok-osztondij/magyar-sportcsillagok (Letöltés: 2017.01.08.)

${ }^{2}$ http://olimpia.hu/adatlap/olimpikon-eletut-program (Letöltés: 2017.01.08.)
6. Mi a sportolók véleménye a személyre szabott, sporton túlmutató fejlesztésről, a lehetséges eszközökről?

\section{Módszerek}

Egy online kérdőíves kutatás biztosította az adatokat a témában megfogalmazott kérdések megválaszolására. A 80, Likert-skálás zárt kérdésből álló kérdőív kidolgozását nemzetközi szakértők egy csoportja végezte a kettős karrier témájával foglalkozó Erasmus+ AC4DC projekt keretében, melynek magyar tagja a Testnevelési Egyetem. A kérdőívek kiküldése magyar sportolók részére közvetetten a sportági szakszövetségek bevonásával történt, valamint azt a szakszövetségek és a projekt honlapján helyzeték el. Magyarországról 38 sportág 320 képviselője töltötte ki (56\% nő, 44\% férfi, átlag életkor 23 év). A tanulmányban a teljes adatállomány töredékét dolgoztuk fel, az adatelemzést a Microsoft Office Excel programjának táblázatában kezeltük. Az adatstruktúrában az oszlopokban voltak az egyes kérdésekre adott válaszok, a sorokban az esetek, anonim válaszadók. Az adatokat egyváltozós eloszlást deskriptív statisztikai módszerrel elemeztük. A kategoriális változók esetében azt kerestük, hogy az egyes válaszkategóriákat hányan választották, továbbá hogy egy kategóriát az összes válaszadó hány százaléka jelölte meg. A kapott válaszok eloszlását kör, illetve oszlopdiagramokon ábrázoltuk. A teljes eredményt a projektcsoport a dc4ac.hu honlapon helyezi majd el 2017 májusában.

A kérdőív 80 kérdéséből azokat ismertetjük a következő, eredmények fejezetben, melyek válaszai relevánsak a tanulmány kérdéseire.

\section{Eredmények}

Ebben a pontban a kérdések bemutatásával ismertetjük az eredmények egy részét.

1. „Mi volt az oka annak, ha olyan helyzetbe került, hogy választania kellett a sportkarrier és a tanulmányai között,?"

A válaszadók $74 \%$-a esetében a sportkarrier és a tanulmányok közötti választás kényszere a tanulmányok és a sport időbeosztásának ütközéséből adódott.

2. „Mennyit gondol arra, hogy mit fog csinálni sportolói karrierje után?” (1: semennyire, 7: nagyon) 
Az 1-7 pontos skálán adott válaszok alapján a sportolók kétharmada sokat gondol arra, hogy mit fog csinálni sportkarrierje után.

3. A fö támogatókról kérdezve a sportolók egyértelműen jelezték, hogy nem a sportszervezetekre, hanem a közvetlen szülöi-családi, baráti/ élettársi és az edzői támogatásra tudtak/tudnak támaszkodni.

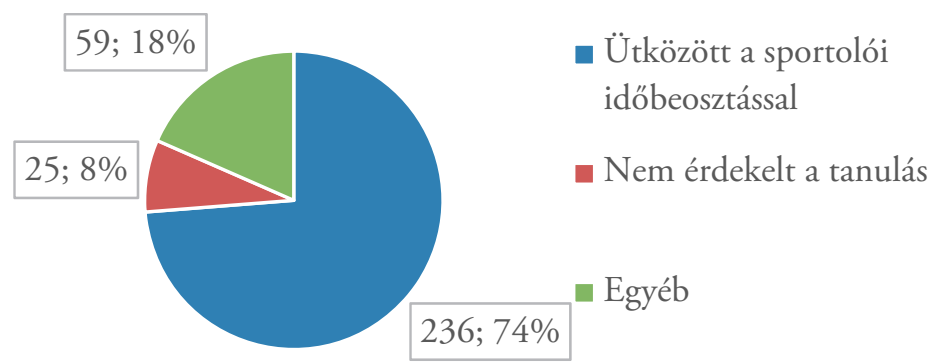

1. ábra. Tanulmány és sportkarrier közötti választás indoklása [Forrás: saját szerkesztés]

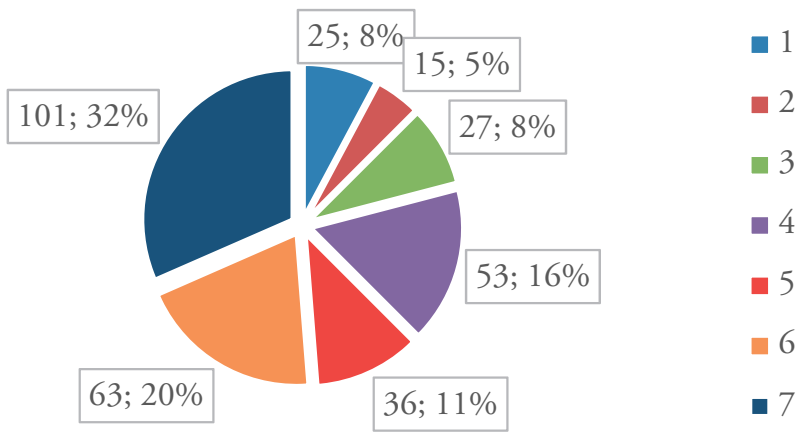

2. ábra. Mennyit gondolnak arra a sportolók, hogy mit fognak csinálni sportkarrierjük után [Forrás: saját szerkesztés]

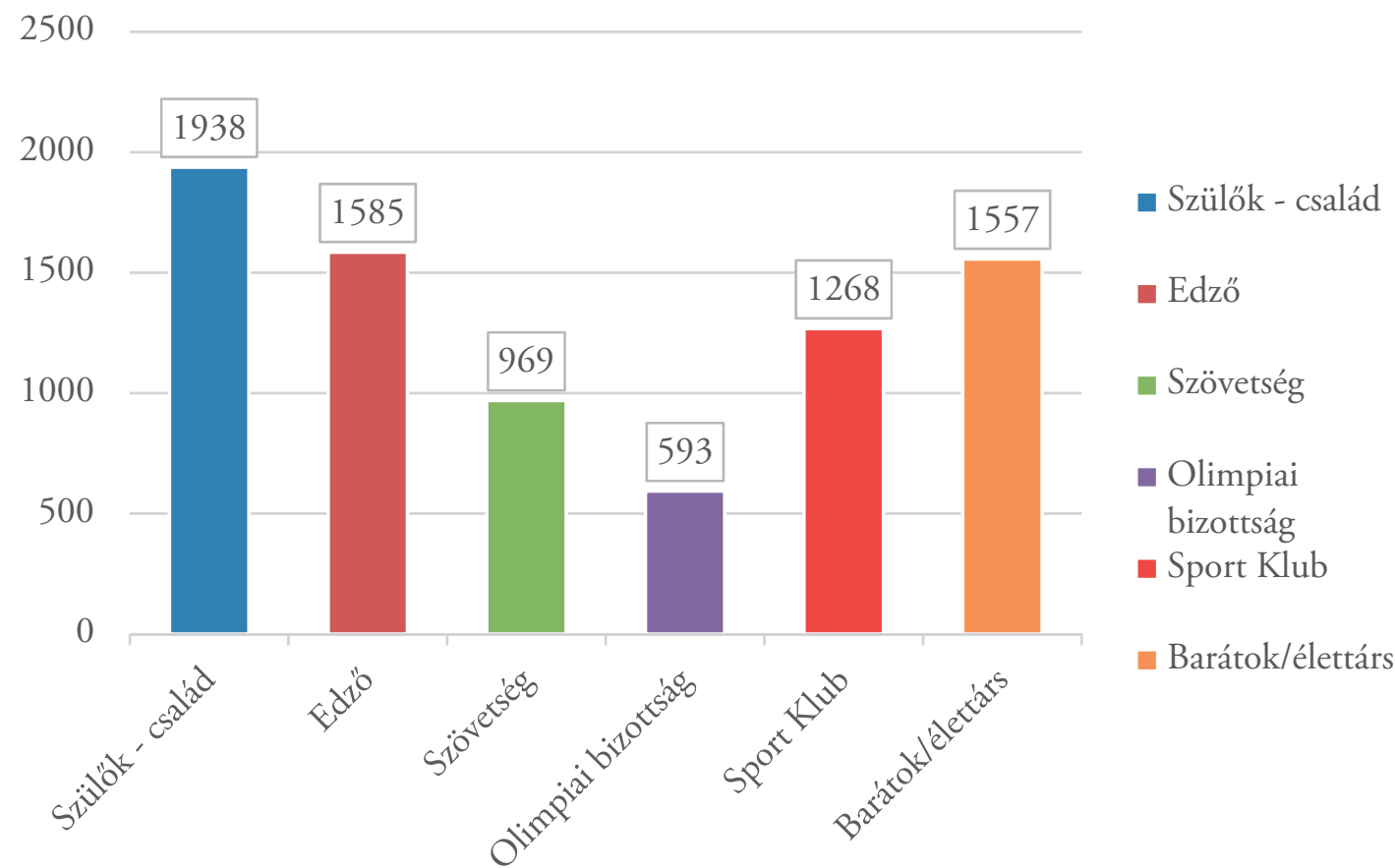

3. ábra. Kik támogatják a sportolói karrierben (fö) [Forrás: saját szerkesztés] 
$\mathrm{Az}$ oszlopdiagram az összesen adott pontok mennyiségét ábrázolja. Ebből az látszik, hogy a karrierjük lépcsőfokain mennyire fontos a szülő-család támogatása.
4. „Milyen mértékben gondolja, hogy szükséges egy mentort kijelölni, aki támogatja Önt a sportolói karrierje utáni váltásban és abban, hogy kettős karrierje lehessen?” (1: semennyire, 7: nagyon)

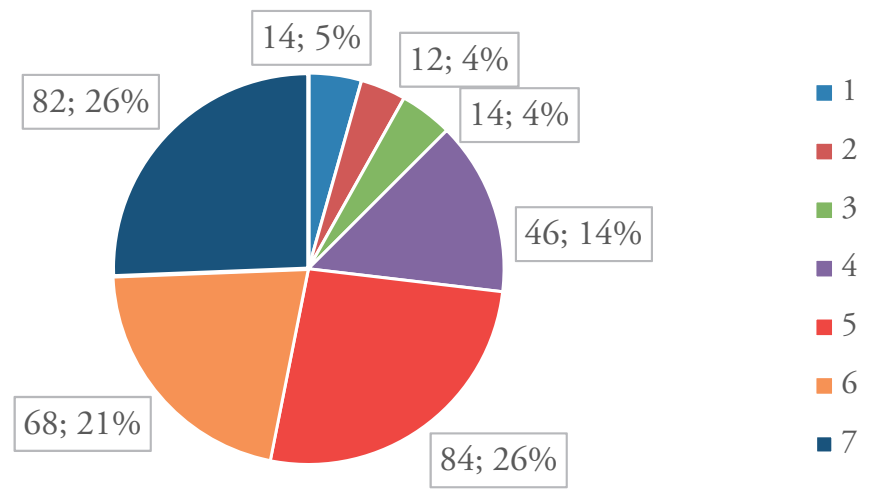

\section{4. ábra. Mentor szükségessége [Forrás: saját szerkesztés]}

A kérdőívet kitöltők nagytöbbsége (73\%) válaszában a középértéknél nagyobb értéket adott, tehát a sportszervezetek részéről az egyik leghasznosabb fejlesztési irány az lehetne, ha mentor-programot indítanának a sportolók sportkarrier alatti és utáni (civil, szakmai) életük menedzseléséhez.

5. További, a képzéssel kapcsolatos támogató eszközökre is rákérdezett a kérdőív: „Néhány ország stratégiákat fejlesztett ki arra, hogy a sportolókat támogassák a tanulásban és sportban. Az alábbiak közül melyek segítenének Önnek és milyen mértékben? (1: semennyire, 7: nagyon)”. Az alábbi kategóriákra adott válaszok abszolút értékét jelöljük az oszlopdiagramban, ahol minél magasabb az oszlop, annál nagyobb értéket, tehát fontosságot kapott az adott kategória.

- Online oktatási felület, amely a saját ütemben történő önképzésre összpontosít

- Távoktatás

- Az oktatási időtartam meghosszabbítása

- Az órák összesürítése intenzív modulokká

- Rugalmas vizsgarend

- Csak olyan egyetem órákon való részvétel, amelyek ajánlott kompetenciánként vannak elismerve

- Sportszervezeteknél való önkéntesség, amelynek célja egy ahhoz kapcsolódó későbbi munkal karrier
- Gyakornoki munka, amelynek célja egy adott téren való munka/karrier

- Módosított tanterv

- Korrepetálás/további támogatás a tanulásban 6. További, már nemcsak tanuláshoz kapcsolható támogató eszközök preferenciájáról is kérdezték a sportolókat. „Milyen mértékben gondolja hasznosnak az alábbiakat a sportolói karrier utáni következő életszakaszba való átállás szempontjából? (1: semennyire, 7: nagyon”). Az alábbi kategóriákra adott válaszok abszolút értékét jelöljük az oszlopdiagramban, ahol: minél magasabb az oszlop, annál nagyobb értéket, tehát fontosságot tulajdonítottak annak a támogató eszköznek.

1. Személyiségfejlesztő kurzusok

2. Szakképzési tájékoztatók (nincs adat: itt sajnos technikai hiba miatt nem rögzítette a rendszer a válaszokat)

3. Karrier tanácsadás és tervezés

4. Életstílus menedzsment

5. Az átállásra felkészítő és az átállással megbirkózás képességének elsajátítása

6. Krízis intervenció

7. Oktatási tanácsadás és információ

8. Munkaügyi tanácsadás és információ, új munkára való felkészítés

9. Ösztöndíjak 




5. ábra. Támogatási lehetőségek az oktatásban és a sportban (fö) [Forrás: saját szerkesztés]

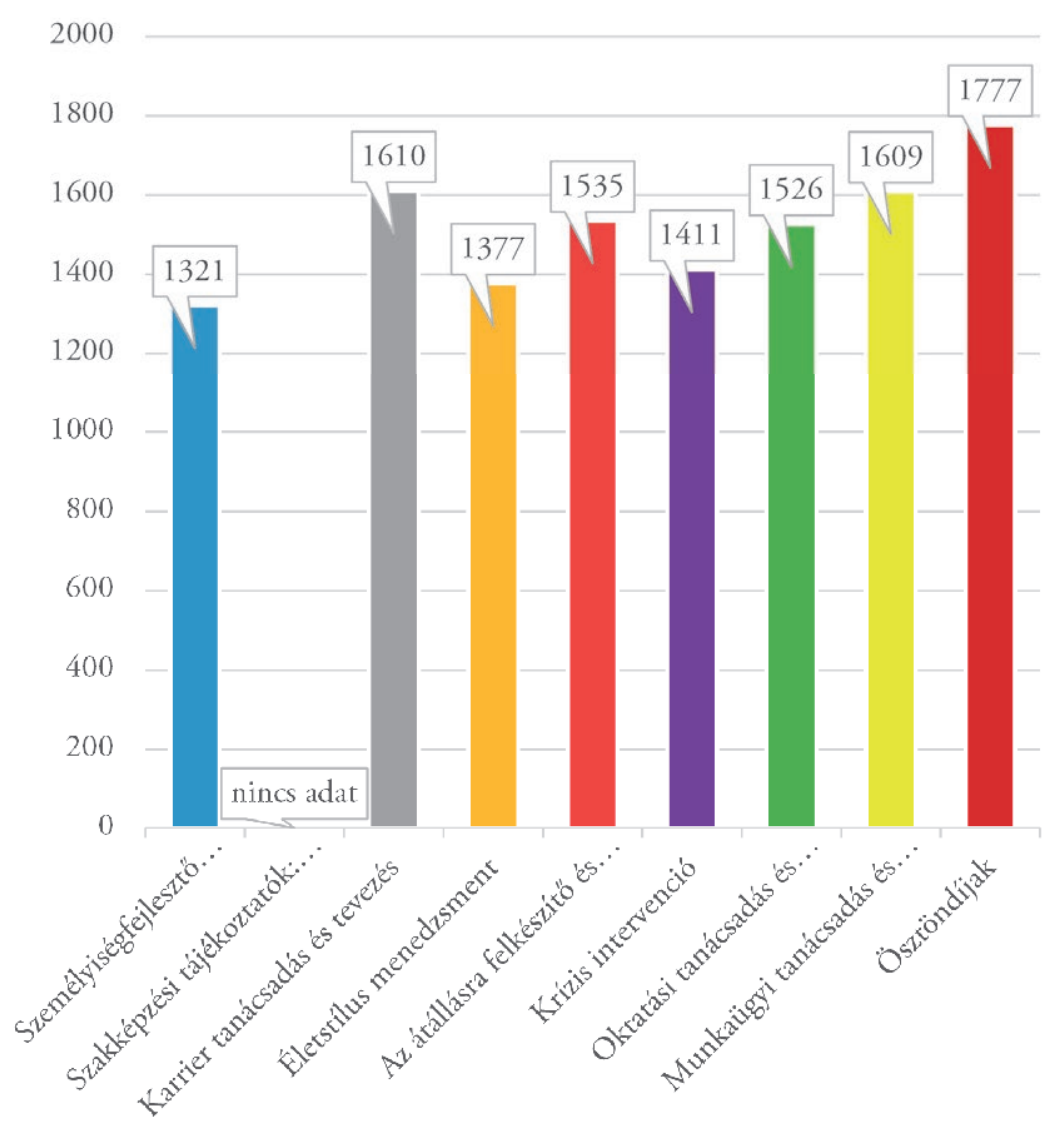

6. ábra. Sportkarrier utáni élethez való segítség formái (fö) [Forrás: saját szerkesztés] 


\section{Megbeszélés}

A 4. pontban megfogalmazott 6 kérdésre az alábbiakban foglaljuk össze a kapott válaszokat.

A tanulmány célja az volt, hogy rálátást kapjunk a sportolók véleményére a magyarországi sportolói kettős karrier helyzetéről, fejlesztési irányairól.

1. Mivel a válaszadók $74 \%$ állította azt, hogy amikor választania kellett a sport és a tanulás között, az azért volt, mert a tanulmányok ütköztek a sportolói időbeosztással, ezért egyértelmű következtetés, hogy javítani kell az iskola/egyetem és a sportszervezetek párbeszédén, együttműködésén, és az egyént is segíteni kell az időbeosztás és a terhek kiegyensúlyozásában.

2. A sportolók sokat gondolnak a civil életben történő karrierépítésükre, és a többi kérdésre adott válaszok alapján tudják is, hogy mi segítene nekik a kettős karrier építésében.

3. A sportoló közvetlen és személyes környezete ('́gy pl. az edzői is) sokkal jobban támogatja a kettős karrier területén, mint a vele érintkező sportszervezetek.

4. A sportolók fontosnak érzik, hogy a civil életre való átállással kapcsolatban tanácsadáson, programokon vehessenek részt.

5. Több eszközt is megjelöltek, melyek személyre szabott feltételként segítenék a sportolókat tanulmányaik során, pl. rugalmas vizsgarend, gyakornoki, önkéntes munka.

6. A képzési kérdéseken túl számos személyre szabott fejlesztő megoldás és eszköz fontosságát hangsúlyozták a kérdőívben a magas értékek adásával, pl. karrier tanácsadás és tervezés, az „átállásra” való felkészítés, munkaügyi tanácsadás és információ, új munkára való felkészítés. Európa szerte ismert téma, de hazánkban kevés jó gyakorlattal rendelkezik a sportolók kettős karrierjének rendszerszintű, fenntartható támogatása. A Magyarországon működő két támogatási program kezdeményezettjeinek köre szűk, hiszen csak azokat a felsőoktatásban tanuló legtehetségesebb sportolókat támogatja, akik tanulmányaik ideje alatt eséllyel rendelkeznek nemzetközi versenyen való éremszerzésre.

A tanulmányban az ilyen irányú fejlesztésekhez szakpolitikai szempontból alapot képező hazai és európai uniós dokumentumok bemutatása mellett, legfőkképp a magyar sportolók véleményét, igényeit ismertetjük. Ehhez egy kérdőíves kutatás biztosított adatot ( $\mathrm{n}=320,38$ sportág).
A kutatás eredményei közül kiemeljük, hogy a sportolók úgy értékelték, hogy az összes, 19 féle támogatási eszközre szükségük van: pl. személyiségfejlesztő kurzusok, oktatási tanácsadás; ösztöndíjak; karrier tanácsadás és tervezés; az átállásra felkészítő és az átállással megbirkózni tudó képességek elsajátítása; módosított tanterv; rugalmas vizsgarend; korrepetálás/további támogatás a tanulásban, képzési időtartam meghosszabbítása; távoktatás; online oktatási felület, amely a saját ütemben történő önképzésre összpontosít; sportszervezeteknél való önkéntes/gyakornoki munka, amelynek célja egy ahhoz kapcsolódó későbbi karrier.

\section{Következtetések}

Mivel magyar sportolói hangok, felmutatott érdekek, igények eddig nem voltak tapasztalhatók, és az unió, a sport területén létező puha kompetenciája sem kötelezi a tagállami, így a magyar sport állami és nem állami vezetését, hogy hajtsa végre a több uniós szakpolitikai dokumentumban rögzített iránymutatásokat és ajánlásokat. A kutatásunkban született és közreadott eredmények várhatóan közelebb viszik a magyar sport több szereplőjét ahhoz, hogy több oldalról is továbbvizsgálja a sportolók ilyen irányú támogatásának szükségességét.

\section{Irodalom}

1. EUMSZ (2010): Az Európai Unió müködéséröl szóló szerzödés egységes szerkezetbe foglalt változata. Az Európai Unió Hivatalos Lapja, http://eur-lex.europa.eu/legal-content/ HU/TXT/HTML/?uri=CELEX:12012E/ TXT\&from=HU

2. Európai Bizottság (2007): $\mathrm{Fe}$ hér könyv a sportról. Brüsszel. http:// eur-lex.europa.eu/legal-content/HU/ TXT/?uri=URISERV\%3Al35010 (Letöltés: 2017.01.08.)

3. Európai Bizottság (2009): A Lisszaboni Szerződés. Brüsszel http://eur-lex.europa. eu/LexUriServ/LexUriServ.do?uri=OJ:C:2 010:083:0001:01:HU:HTML. (Letöltés: 2017.01.08.)

4. Európai Bizottság (2011a): A Bizottság közleménye az Európai Parlamentnek, a Tanácsnak, az Európai Gazdasági és Szociális Bizottságnak és a Régiók Bizottságának - A sport európai dimenziójának fejlesztése. Brüsszel. http:// 
eur-lex.europa.eu/LexUriServ/LexUriServ.do ?uri=COM:2011:0012:FIN:HU:PDF. (Letöltés: 2017.01.08.)

5. Európai Bizottság (2011b): A Tanács és a tagállamok kormányainak a Tanács keretében ülésező képviselői által elfogadott állásfoglalás a sportra vonatkozó uniós munkatervröl (2011-2014). Brüsszel http://eur-lex. europa.eu/LexUriServ/LexUriServ.do?uri=OJ :C:2011:162:0001:0005:HU:PDF. (Letöltés: 2017.01.08.)

6. Európai Bizottság (2012): A sportolók kettös karrierjéröl szóló Európai Uniós iránymutatások. Brüsszel. (Letöltés: 2017.01.08.)

7. Európai Bizottság (2014): A Tanács és a tagállamok kormányainak a Tanács keretében ülésező képviselői által elfogadott állásfoglalás a sportra vonatkozó uniós munkatervröl (2014-2017). Brüsszel. http://eur-lex.europa. eu/legal-content/HU/TXT/HTML/?uri=CE LEX:42014Y0614(03)\&from=EN. (Letöltés: 2017.01.08.)
8. Farkas Judit (2012): Az Európai Unió sport szakpolitikája, föbb dokumentumai és ezek hazai implementációjának elemzése. Szakdolgozat. Pázmány Péter Katolikus Egyetem, Jogés Államtudományi Kar, Budapest.

9. Kozsla Tibor, Bardocz-Bencsik Mariann és Farkas Judit (2014): Oktatás, képzés, képesités és kettös karrier a sportban. A fizikai aktivitás és a sport magyarországi dimenzióinak feltárása címü TÁMOP 6.1.2/11/2-2012-02 projekt keretében végzett módszertani kutatás összegző tanulmány és az EU iránymutatásainak magyarországi implementációja, Budapest. 